\title{
Identification of a Cell-Surface Protein Involved in PC12 Cell- Substratum Adhesion and Neurite Outgrowth on Laminin and Collagen
}

\author{
David C. Turner, ${ }^{1}$ Leonard A. Flier, ${ }^{1}$ and Salvatore Carbonetto ${ }^{2}$ \\ 'Department of Biochemistry and Molecular Biology, SUNY Health Science Center at Syracuse, Syracuse, New York \\ 13210 and ${ }^{2}$ Centre for Neuroscience Research, McGill University, Montreal General Hospital Research Institute, Montreal, \\ P.Q. H3G 1A4, Canada
}

\begin{abstract}
On substrata coated with laminin or native collagen (Types I/III), PC12 cells employ an active adhesion mechanism (i.e., one inhibited at low temperature, by azide or in the absence of divalent cations) to attach and extend neurites; on substrata coated wlth wheat germ agglutinin (WGA) or polylysine, by contrast, $P C 12$ cells attach via a passive mechanism and fail to extend neurites (Turner et al., 1987). This paper reports the isolation of 2 monoclonal antibodies (3A3 and 1B1) that promote retraction of neurites extended on laminin and collagen. In studies of initial cell attachment, 3A3 inhibited active attachment to laminin or collagen but not passive attachment to WGA or polylysine, whereas 1B1 inhibited both active and passive attachment. The more potent of the antibodies, 3A3, precipitates 2 radioactive protein bands (of approximately 185 and $125 \mathrm{kDa}$ ) from $1 \%$ Nonidet P-40 extracts of metabolically labeled PC12 cells. The properties of these proteins suggest that the antigen recognized by $3 \mathrm{~A} 3$ is a member of the integrin family of matrix receptors. The other monoclonal antibody, 1B1, reacts with many PC12 proteins, including both bands precipitated by $3 \mathrm{A3}$. The available data strongly suggest that an integrin with specificity for both laminin and collagen mediates PC12 adhesion to the substratum at both the cell body and the neurite growth cone.
\end{abstract}

During development and regeneration growing nerve fibers must make their way through a meshwork of molecules, termed the extracellular matrix (ECM), which fills most of the space between cells in their paths. In vivo the ECM is involved in the migration of neural crest cells during development (Boucaut et al., 1984; Bronner-Fraser, 1986), as well as in the regeneration of peripheral nerves (Sandrock and Matthew, 1987) and myoneural synapses (Nitkin et al., 1983). In cell culture, the adhesive interactions of neurons with purified ECM molecules such as collagen, fibronectin, and laminin strongly influence the extent (Akers et al., 1981; Carbonetto et al., 1982, 1983; Man-

\footnotetext{
Received July 28, 1988; revised Feb. 21, 1989; accepted Mar. 2, 1989.

We thank Carol Schindler for technical assistance. This research was supported by grants to D.C.T. from the Competitive Research Grants Program of the U.S. Department of Agriculture (86-CRCR-1-1947) and to S.C. from the National Institutes of Health (NS 19068), the Medical Research Council of Canada (MA 10182), and the Spinal Cord Research Foundation.

Correspondence should be addressed to S. Carbonetto, Centre for Neuroscience Research, McGill University, Montreal General Hospital Research Institute, 1650 Cedar Avenue, Montreal, Quebec H3G 1A4, Canada.

Copyright (C) 1989 Society for Neuroscience 0270-6474/89/093287-10\$02.00/0
}

thorpe et al., 1983) and direction (Turner and Carbonetto, 1984; Hammarback et al., 1985) of neurite growth. Laminin, in particular, stimulates neurite outgrowth from dorsal root or sympathetic ganglia, which otherwise require exogenous nerve growth factor (NGF) (Edgar et al., 1984; Lander et al., 1985). In addition, laminin supports growth of CNS neurons more effectively than fibronectin or collagen (Rogers et al., 1983), stimulates transdifferentiation of pigmented epithelial cells into neurons (Reh et al., 1987) and induces tyrosine hydroxylase in adrenal chromaffin cells (Acheson et al., 1986). These hormonelike effects of laminin have generated considerable interest in identification of receptors for laminin and their relationship to those for neurotrophic factors.

Our initial approach to studying neuron-ECM interactions was to characterize the adhesion of PC12 cells to culture substrata coated with purified proteins. PC12 cells, an established cell line derived from a rat pheochromocytoma (Greene and Tischler, 1976), respond to treatment with NGF by acquiring many of the properties of sympathetic neurons (Greene and Tischler, 1982; Guroff, 1985), notably the ability to extend neurites on suitable substrata (Schubert and Whitlock, 1977; Greene, 1978; Vlodavsky et al., 1982; Heidemann et al., 1985), including laminin (Tomaselli et al., 1987; Turner et al., 1987). We showed (Turner et al., 1987) that PC1 2 cells attach by an "active" mechanism (Grinnell, 1978) to dishes coated with collagen and laminin; active attachment requires $\mathrm{Mg}^{2+}$ and is inhibited at low temperatures and in the presence of sodium azide. PC12 cells also attach well to certain other substrata, e.g., surfaces coated with wheat germ agglutinin (WGA) or poly-L-lysine but do so via a "passive" mechanism that requires no exogenous divalent cation and functions at low temperature or in the presence of azide. On still other substrata, such as gelatin (denatured collagen) and fibronectin, PC12 cells attach poorly (Turner et al., 1987). Neurite outgrowth by PCl 2 cells on laminin or collagen also requires $\mathrm{Mg}^{2+}$. PC1 2 cells fail to extend neurites on laminin and collagen in the absence of divalent cations or in the presence of $\mathrm{Ca}^{2+}$ alone, but they do so when cultured in medium containing $\mathrm{Mg}^{2+}$ alone or $\mathrm{Mg}^{2+}$ plus $\mathrm{Ca}^{2+}$. PC12 cells fail to extend neurites on WGA or polylysine whether $\mathrm{Mg}^{2+}$ is present or not. On the basis of these results, we concluded (Turner et al., 1987) that the active $\left(\mathrm{Mg}^{2+}\right.$-dependent) attachment mechanism is required to stabilize cell-matrix adhesion at the growth cone and thus permit neurite outgrowth. Taking into account additional evidence, including retention of ability to adhere to both laminin and collagen after protease treatment of cells and the similar 
kinetics of attachment on laminin and collagen, we postulated the existence of a dual laminin/collagen receptor on the surfaces of PC12 cells (Turner et al., 1987).

In this paper we provide strong additional evidence for a dual laminin/collagen receptor. We have isolated a monoclonal antibody, 3A3, that interferes with neurite outgrowth by $\mathrm{PC} 12$ cells on laminin or collagen. This antibody inhibits active, but not passive, attachment of PC12 cells in culture. Furthermore, we have used $3 \mathrm{~A} 3$ to identify the proposed laminin/collagen receptor: $3 \mathrm{~A} 3$ immunoprecipitates 2 protein bands from detergent extracts of $\mathrm{PC} 12$ cells. The properties of these bands suggest that they constitute a heterodimeric receptor of the integrin family of matrix receptors.

\section{Materials and Methods}

Culture of PC12 cells. All of the methods were exactly as described previously (Turner et al., 1987). Briefly, cells were routinely passaged in standard medium containing $10 \%$ horse serum and $5 \%$ fetal calf serum. To induce differentiation, cells were "primed" by culturing for $2 \mathrm{~d}$ in standard medium containing $300 \mathrm{ng} / \mathrm{ml} 7 \mathrm{~S} \mathrm{NGF}$. Neurite outgrowth was assessed by culturing primed cells in a defined medium (Bottenstein and Sato, 1979) supplemented with $300 \mathrm{ng} / \mathrm{ml}$ 7S NGF and $1 \mathrm{mM}$ dibutyryl cyclic AMP.

Production of monoclonal antibody $(m A b)$. Balb/cJ mice (Jackson Laboratories, Bar Harbor, ME) were immunized by 4 intraperitoneal injections of $3 \times 10^{6}$ to $1 \times 10^{7}$ unprimed PC12 cells over 5 months. Animals yielding antisera that, at a dilution of $1: 1000$, promoted neurite detachment in the screening assay (see below) were injected twice more (at 3 and $4 \mathrm{~d}$ prior to fusion; final boost: $1 \times 10^{8}$ cells) and used for splenocyte preparation. Using standard methods (Campbell, 1984), 1 $\times 10^{8}$ splenocytes prepared from a single mouse were mixed with 2.5 $\times 10^{7}$ NS- 1 cells and fused by gentle agitation in the presence of $40 \%$ polyethylene glycol (PEG 1600, Sigma) in RPMI 1640 medium. Cells were then diluted to $240 \mathrm{ml}$ with HAT medium (modified from Watt and Watt, 1983): 70\% Iscove's modified Dulbecco medium, $20 \%$ fetal bovine serum, and $10 \%$ NCTC 109 medium containing $100 \mu \mathrm{g} / \mathrm{ml}$ endothelial cell growth supplement (Collaborative Research), $0.1 \mathrm{mM}$ sodium pyruvate, $0.1 \mathrm{~m}$ nonessential amino acid mix (Gibco), $0.1 \mathrm{~mm}$ hypoxanthine, $0.4 \mu \mathrm{M}$ aminopterin, and $32 \mu \mathrm{M}$ thymidine. Aliquots (1 $\mathrm{ml}$ ) of the cell suspension were distributed in ten 24-well tissue culture plates. Preclonal supernates from growth-positive wells were tested for activity in promoting neurite retraction on both collagen and laminin substrata (see below). Cells from positive wells were cloned by limiting dilution on splenocyte feeder layers in 96 -well tissue culture plates. The success of cloning was confirmed by subcloning, using immunofluorescence (see below) to screen the supernates, and cloned sublines were frozen (Campbell, 1984). Two hybridomas that produce inhibitory $\mathrm{mAb}$ were obtained; they are designated $3 \mathrm{~A} 3$ and $1 \mathrm{~B} 1$. Monoclonal supernates from $3 \mathrm{~A} 3$ clones consistently showed greater inhibitory activity than those from 1B1 clones. Antibody subtyping (by double immunodiffusion with reagents from Meloy, Springfield, VA) showed 3A3 to be an $\mathrm{IgG}_{1}$, while $1 \mathrm{~B} 1$ is an $\mathrm{IgG}_{3}$.

Screening for inhibitory $m A b$. Wells of 96-well plates (Nunc ImmunoPlate I) were coated with calf skin collagen (Sigma acid-solublc type III, consisting primarily of collagen Type I with a small percentage of Type III) or mouse laminin (prepared from EHS sarcoma according to Timpl et al., 1982, or purchased from BRL) by incubating them at $37^{\circ} \mathrm{C}$ overnight with $100 \mu \mathrm{l}$ of a $20 \mu \mathrm{g} / \mathrm{ml}$ solution in $0.05 \mathrm{M}$ sodium carbonate buffer, pH 9.6 (Rogers et al., 1983). After rinsing the wells 3 times with $100 \mu \mathrm{l}$ of PBS, $100 \mu \mathrm{l}$ aliquots of a suspension of NGFprimed PC 12 cells $\left(2 \times 10^{4}\right.$ cells $/ \mathrm{ml}$ in modified defined medium) were introduced into the wells, and the cells were allowed to extend neurites for $18-48 \mathrm{hr}\left(37^{\circ} \mathrm{C}, 5 \% \mathrm{CO}_{2}\right)$ before use. Screening assays were initiated by adding $100 \mu \mathrm{l}$ of culture supernate (or, for controls, diluted antiserum or fresh medium) per well; all tests were done in duplicate. After 4-6 hr, $20 \mu \mathrm{l}$ of $25 \%$ glutaraldehyde was pipetted into each well. Following fixation for at least $60 \mathrm{~min}$, the multiwell plates were gently rinsed with water and stained with Coomassie blue. Activity in promoting cell detachment and neurite retraction was assessed by inspection under a dissecting microscope. With the most active samples, the number of adherent cells was greatly reduced compared.with controls, and the remaining cells were almost all rounded; less active samples resulted in variable reduction in the number of cells with ncurites or with irregular contours. For later documentation and quantitation of the neurite retraction and cell detachment promoted by purified $\mathrm{mAb}$, cells were plated in $35 \mathrm{~mm}$ dishes and photographed using phase-contrast optics.

Purification of $m A b$. Subcloned hybridoma cells known to secrete either $3 \mathrm{~A} 3$ or $1 \mathrm{Bl}$ were injected intraperitoneally into pristane-primed mice, and ascites fluids were collected at intervals thereafter (Campbell, 1984). The method of Buck et al. (1986) was used to purify 3 A3. Briefly, frozen ascites fluid was thawed, clarified by centrifugation $(40,000 \times g$ for $15 \mathrm{~min}$ ), and brought to $50 \%$ saturation with ammonium sulfate. Material that precipitated was resuspended, dialyzed against $20 \mathrm{~mm}$ Tris/20 mM NaCl, $\mathrm{pH} \mathrm{7.2,} \mathrm{and} \mathrm{applied} \mathrm{to} \mathrm{a} \mathrm{DEAE-Affi-Gel} \mathrm{Blue} \mathrm{column}$ equilibrated with the same buffer. Antibody eluted with a linear 20 $100 \mathrm{~mm} \mathrm{NaCl}$ gradient was essentially free of contaminating material, as judgcd by SDS-PAGE (not shown). The same procedure could not be used for IBI because of the tendency of this $\mathrm{mAb}$ to precipitate upon freezing or dialysis against Tris/ $\mathrm{NaCl}$. Substantial purification was achieved, however, by taking the precipitate that formed when ascites fluid was dialyzed against $\mathrm{Tris} / \mathrm{NaCl}$ and redissolving in $50 \mathrm{~mm}$ sodium carbonate buffer, $\mathrm{pH}$ 9.6. Material purified in this way was judged to be at least $70 \%$ pure by SDS-PAGE (not shown). Unless otherwise indicated, the purified mAb preparations just described were used in all experiments.

Immunofluorescence. Cultures of $\mathrm{PC} 12$ or other cells were washed twice with PBS, fixed for $30 \mathrm{~min}$ at room temperature with $3 \%$ formaldehyde in PBS containing $0.1 \mathrm{mM} \mathrm{CaCl}$ and $0.1 \mathrm{mM} \mathrm{MgCl}_{2}$, and incubated for $1 \mathrm{hr}$ with $0.1 \%$ glycine in PBS. After washing with PBS and draining off excess fluid, tissue paper swabs were drawn in a crisscross pattern across the dish surface, leaving a number of wet ficlds separated by dry strips that could be reacted with different hybridoma culture supernates or various dilutions of $\mathrm{mAb}$ in borate-buffered saline. Incubation with primary $\mathrm{mAb}$ was for $30 \mathrm{~min}$ at room temperature, followed by 3 washes over $15 \mathrm{~min}$ with PBS, reaction with rhodaminecoupled goat antibodies against mouse IgG (Cappell; 1:50 dilution in borate-buffered saline) for $30 \mathrm{~min}, 3$ washes with PBS over $15 \mathrm{~min}$, and mounting in PBS-buffered glycerol under a glass coverslip. Fluorescence optics and photography were as described earlier (Turner et al., 1983). The same methods were used for fluorescent antibody staining of living cells except that culture medium at $37^{\circ} \mathrm{C}$ was used for washes, antibody dilutions and mounting, and that times were shortened by about half.

Attachment assay. Unless otherwise stated, the methods for coating plates and for measuring the initial attachment of radiolabeled PC12 cells were exactly as described earlier (Turner et al., 1987). Briefly, polystyrene petri dishes $(35 \mathrm{~mm}$ diameter, Falcon 1008$)$ were coated with a given protein by incubating at $37^{\circ} \mathrm{C}$ overnight with $1 \mathrm{ml}$ of a 10 $\mu \mathrm{g} / \mathrm{ml}$ solution in $0.05 \mathrm{M}$ sodium carbonate buffer, $\mathrm{pH} 9.6$. After 3 rinses with PBS, $2 \mathrm{ml}$ of Hepes-buffered Hanks balanced salt solution containing $20 \mathrm{mg} / \mathrm{ml} \mathrm{BSA}$ and any agents to be tested were added to each dish. The assay was started by introducing $100 \mu \mathrm{l}$ aliquots of ${ }^{35} \mathrm{~S}-\mathrm{me}$ thionine-labeled cells into each dish (final concentration: $1-3 \times 10^{5}$ cells/dish). After $60 \mathrm{~min}$ at $37^{\circ} \mathrm{C}$, the medium was aspirated off, the dishes were rinsed twice with PBS, attached cells were lysed with $1 \%$ Triton $\mathrm{X}-100$, and the lysate was transferred to scintillation vials for counting. Percentage attachment is defined as (radioactivity in lysate of attached cells)/(radioactivity in cells added to assay) $\times 100$. To conserve $\mathrm{mAb}$, a scaled-down version of this procedure (using 96-well Nunc Immunoplates; assay volume, $100 \mu \mathrm{l}$ ) was used in one series of experiments (as indicated in Results); for reasons not understood, maximum attachment to laminin-coated plastic multiwell plates was considerably lower than in the standard procedure.

Cell extracts. Unlabeled extract was prepared from approximately 9 $\times 10^{8} \mathrm{PC1} 2$ cells harvested from $20175 \mathrm{~cm}^{2}$ flasks that each contained $300 \mathrm{ml}$ of standard medium (Turner et al., 1987). These cells were rinsed 4 times in PBS and then resuspended in $300 \mathrm{ml}$ of extraction buffer (PBS containing 1\% Nonidet P-40, 0.2 mM phenylmethylsulfonyl fluoride, $2 \mu \mathrm{g} / \mathrm{ml}$ leupeptin, $1 \mu \mathrm{M}$ pepstatin, and $1 \mathrm{mM} \mathrm{MgCl}_{2}$ ) and incubated for $30 \mathrm{~min}$ on ice with occasional stirring. Nonextracted material was removed by centrifugation for $30 \mathrm{~min}$ at $96,000 \times \mathrm{g}$ in a Beckman type 35 rotor and the supernate was frozen at $-80^{\circ} \mathrm{C}$. Extract containing metabolically labéled proteins was prepared by a similar procedure from approximately $1 \times 10^{8}$ cells that had been cultured for $3 \mathrm{~d}$ with $5 \mu \mathrm{Ci} / \mathrm{ml}$ of ${ }^{35} \mathrm{~S}$-methionine and ${ }^{35} \mathrm{~S}$-cysteine (Tran ${ }^{35} \mathrm{~S}-$ label, ICN) in standard medium made with methionine-free MEM.

Coupling of $m A b$ lo beads. Purified 3A3 was coupled to Affi-Gel 10 (Bio-Rad) according to the manufacturer's instructions. Briefly, $11 \mathrm{ml}$ 
of a $6 \mathrm{mg} / \mathrm{ml}$ solution of $3 \mathrm{~A} 3$ were dialyzed against coupling buffer $(0.1$ $M$ Hepes, $\mathrm{pH} 8.0$, containing $80 \mathrm{mM} \mathrm{CaCl}$ ) and centrifuged for $20 \mathrm{~min}$ at $40,000 \times \mathrm{g}$. The supernate was then incubated overnight at $4^{\circ} \mathrm{C}$ with $4.3 \mathrm{ml}$ (packed bed volume) of Affi-Gel 10 beads that had been washed in coupling buffer. Following the coupling reaction, the supernate was recovered and the beads were incubated for $1 \mathrm{hr}$ at $4^{\circ} \mathrm{C}$ with $10 \mathrm{ml}$ of $0.1 \mathrm{M}$ ethanolamine in coupling buffer to block any unreacted sites. The beads, designated " $3 \mathrm{~A} 3$-beads," were then rinsed exhaustively with $1 \%$ Nonidet P-40 in PBS and stored at $4^{\circ} \mathrm{C}$ in the same buffer containing $0.02 \%$ sodium azide. Coupling efficiency exceeded $90 \%$.

Immunoprecipitation. Unlabeled cell extract $(100 \mathrm{ml})$ was shaken gently overnight at $4^{\circ} \mathrm{C}$ with $2.5 \mathrm{ml}$ of $3 \mathrm{~A} 3$ beads that had been previously washed with rinse buffer $\left(0.1 \%\right.$ Nonidet P- $40,1 \mathrm{mM} \mathrm{MgCl}_{2}$ in PBS). The beads were then transferred to a column and washed with $200 \mathrm{ml}$ of rinse buffer, after which bound material was eluted with 5 $\mathrm{ml}$ of $0.1 \mathrm{M}$ glycine, $\mathrm{pH} 2$, containing $1 \%$ Nonidet P-40; the eluate was immediately neutralized by dropwise addition of $1 \mathrm{M}$ Tris base and stored at $-20^{\circ} \mathrm{C}$. The beads were stripped with $5 \mathrm{ml}$ of nonreducing sample buffer (3\% SDS, 10\% glycerol in $60 \mathrm{~mm}$ Tris: Laemmli, 1970), rinsed with $100 \mathrm{ml}$ of rinse buffer, and stored for re-use. Immunoprecipitations of metabolically labeled proteins were performed by mixing $400 \mu \mathrm{l}$ samples of thawed and recentrifuged extract of radiolabeled cells with $\mathrm{mAb}$ and with $60 \mu \mathrm{l}$ of packed agarose beads coupled to goat antibodies against mouse IgG (Sigma), shaking for $20 \mathrm{hr}$ at $4^{\circ} \mathrm{C}$, and spinning down the beads $(600 \times g, 10 \mathrm{~min})$. The beads were washed 6 times with $0.1 \%$ Nonidet P-40 in PBS and then eluted by incubating for $15 \mathrm{~min}$ at $37^{\circ} \mathrm{C}$ with SDS sample buffer (either with or without $6 \%$ mercaptoethanol) and pelleting to remove the beads (Miller et al., 1986).

Electrophoresis ( $S D S-P A G E$ ). Proteins were separated by electrophoresis in slab gels according to Laemmli (1970), with the following modifications:

1. Immunoprecipitates of unlabeled proteins. Eluate from 3A3 beads was mixed with an equal volume of reducing or nonreducing sample buffer, heated at $60^{\circ} \mathrm{C}$ for $10 \mathrm{~min}$, and separated in a $0.75 \mathrm{~mm}$ slab gel ( $5 \%$ resolving gel with a $3.5 \%$ stacking gel). Protein bands were detected by silver staining according to Merrie et al. (1981).

2. Immunoprecipitates of labeled proteins. Extract mixed with an equal volume of sample buffer or eluate was heated at $70^{\circ} \mathrm{C}$ for $15 \mathrm{~min}$, and separated in a 3-15\% gradient gel (thickness, $1.5 \mathrm{~mm}$ ). After staining with Coomassie blue, the gel was dried and radiolabeled protein bands were detected by exposing the gel to X-ray film.

3. Samples for immunoblotting. Three parts of unlabeled cell extract or eluate from $3 \mathrm{~A} 3$ beads were mixed with 1 part of double-strength nonreducing sample buffer, heated at $60^{\circ} \mathrm{C}$ for $10 \mathrm{~min}$, and separated in a $1.5 \mathrm{~mm}$ slab gel (5-10\% gradient gel with a $3.5 \%$ stacking gel).

Immunoblotting. Using a modification of the method of Towbin et al. (1979), proteins separated by SDS-PAGE were transferred electrophoretically ( $2 \mathrm{hr}$ at $2 \mathrm{~A})$ to Immobilon PVDF membrane (Millipore) in a TE-42 transfer chamber (Hoefer). Following transfer, the Immobilon sheet was rinsed in Tris-buffered saline (TBS: $6.06 \mathrm{~g} /$ liter Tris, $11.69 \mathrm{~g} /$ liter $\mathrm{NaCl}, \mathrm{pH} 7.4$ ) and then cut into strips. The manufacturer's recommendations (Immobilon technical protocol TP008, Millipore) were followed for protein staining. Briefly, strips were washed with several changes of detergent solution $\left(0.3 \%\right.$ Tween-20 in PBS) at $22^{\circ} \mathrm{C}$, followed by a $1 \mathrm{hr}$ incubation at $37^{\circ} \mathrm{C}$. Strips were then stained overnight at $22^{\circ} \mathrm{C}$ with $0.1 \%$ india ink (Hunt Speedball) in detergent solution, rinsed with several changes of detergent, and dried. For antibody reactions, strips were rinsed for $15 \mathrm{~min}$ with blocking buffer ( $5 \%$ Carnation nonfat dry milk in TBS) and then shaken overnight at $4^{\circ} \mathrm{C}$ with $3 \mathrm{ml}$ of primary antibody diluted in blocking buffer. After rinsing with several changes of TBS for $1 \mathrm{hr}$, the strips were immersed in blocking buffer for $15 \mathrm{~min}$ and then shaken for $2 \mathrm{hr}$ at $4{ }^{\circ} \mathrm{C}$ with $40 \mathrm{ng} / \mathrm{ml}{ }^{125} \mathrm{I}$-goat anti-mouse $\mathrm{IgG}$ dissolved in blocking buffer. The strips were then rinsed extensively with TBS, dried, and exposed to X-ray film (Kodak XAR-5) using a Lightning Plus intensifying screen (DuPont).

\section{Results}

Stimulation of neurite retraction and cell detachment by $\mathrm{mAbs}$ The mAbs $3 \mathrm{~A} 3$ and $1 \mathrm{~B} 1$ were detected in functional screening assays by their ability to cause neurite retraction and cell detachment on both laminin and collagen substrata. Of the two, 3A3 was more potent. Treatment of cells with $3 \mathrm{~A} 3$ hybridoma supernates regularly detached most of the cells from test wells, whereas 1B1 supernates resulted in only a modest amount of neurite retraction and cell rounding. This difference is also evident with the purified $\mathrm{mAb}$, as the experiments shown in Figure 1 and Table 1 demonstrate. In the first experiment (Fig. 1), cells in parallel cultures were first allowed to extend neurites for 24 $\mathrm{hr}$, then different concentrations of the $2 \mathrm{mAbs}$ were added to the dishes, and finally, after an additional $6 \mathrm{hr}$, the cultures were fixed and photographed. The greater activity of $3 \mathrm{~A} 3$, per milligram of $\mathrm{mAb}$, in promoting neurite retraction and cell detachment is evident from the photographs. However, whereas both antibodies promote retraction of neurites from the substratum, they appear less active in promoting retraction of neurites that have adhered to cell surfaces (Fig. 1). In the second experiment, designed to minimize cell-cell adhesion and to allow quantitation of the antibody effects, cells were plated at lower density and allowed to extend neurites for only $4 \mathrm{hr}$ before addition of $\mathrm{mAb}$. Also, in this instance, cells were treated with antibody relatively briefly ( $3 \mathrm{hr}$, see Fig. 1) to limit detachment of cells from the substratum. The results (Table 1) clearly show that $3 \mathrm{~A} 3$ and $1 \mathrm{Bl}$ promote retraction in a concentration-dependent manner. After a $3 \mathrm{hr}$ exposure to $1 \mu \mathrm{g} / \mathrm{ml} 3 \mathrm{~A} 3$ or 10 $\mu \mathrm{g} / \mathrm{ml} 1 \mathrm{~B} 1$, total neurite length per standard area was reduced by more than two-thirds. The fraction of cells with neurites as well as the numbers of neurite tips and neurite branch points were also markedly reduced; however, effects on cell detachment were less pronounced.

\section{The 3 A3 antigen is a cell surface antigen}

Immunofluorescent labeling of formaldehyde-fixed, nonpermeabilized PC12 cells with $3 \mathrm{~A} 3$ showed that the antigen is distributed over the entire surface (neurites as well as somata) (Fig. 2). Fluorescent labeling with $1 \mathrm{~B} 1$ was much more intense than with $3 \mathrm{~A} 3$ (Fig. 2). In other experiments (not shown), in which $\mathrm{mAb}$ concentrations were varied over a wide range, 1B1 gave approximately the same fluorescence intensity as a 20-fold higher concentration of 3A3. Patterns of fluorescent labeling similar to those in Figure 2 were observed with living cells (not shown), confirming that the antigenic molecules are exposed on the cell surface. In addition, cell culture dishes coated with $3 \mathrm{~A} 3$ mediated attachment of PC12 cells and, in the presence of NGF, process extension (Fig. 3). These observations confirm that the $3 \mathrm{~A} 3$ antigen is on the cell surface; furthermore, they indicate that the antibody does not induce neurite retraction on laminin and collagen because it is toxic to the cells.

\section{Inhibition of active and passive cell attachment}

In addition to promoting neurite detachment from surfaces coated with laminin or collagen, 3A3 inhibited initial attachment of PC12 cells to either of these substrata (Fig. 4). The concentration of $3 \mathrm{~A} 3$ that gave half-maximal inhibition was about 5 $\mu \mathrm{g} / \mathrm{ml}$. Whereas $3 \mathrm{~A} 3 \mathrm{had}$ noticcably affected neurite retraction at $100 \mathrm{ng} / \mathrm{ml}$ (Table 1), there was little effect on initial attachment at this concentration (Fig. 4); this result confirms the greater sensitivity of the neurite retraction assay chosen for $\mathrm{mAb}$ screening (first noted in preliminary experiments with antisera from mice immunized with $\mathrm{PC} 12$ cells). Even at high concentration $(100 \mu \mathrm{g} / \mathrm{ml}), 3 \mathrm{~A} 3 \mathrm{had}$ only a slight effect on PC12 attachment to polylysine and WGA (Table 2). The selective effect of $3 \mathrm{~A} 3$ on cells cultured on laminin or collagen indicates that 3 A3 specifically inhibits the active attachment mechanism required for neurite outgrowth. 

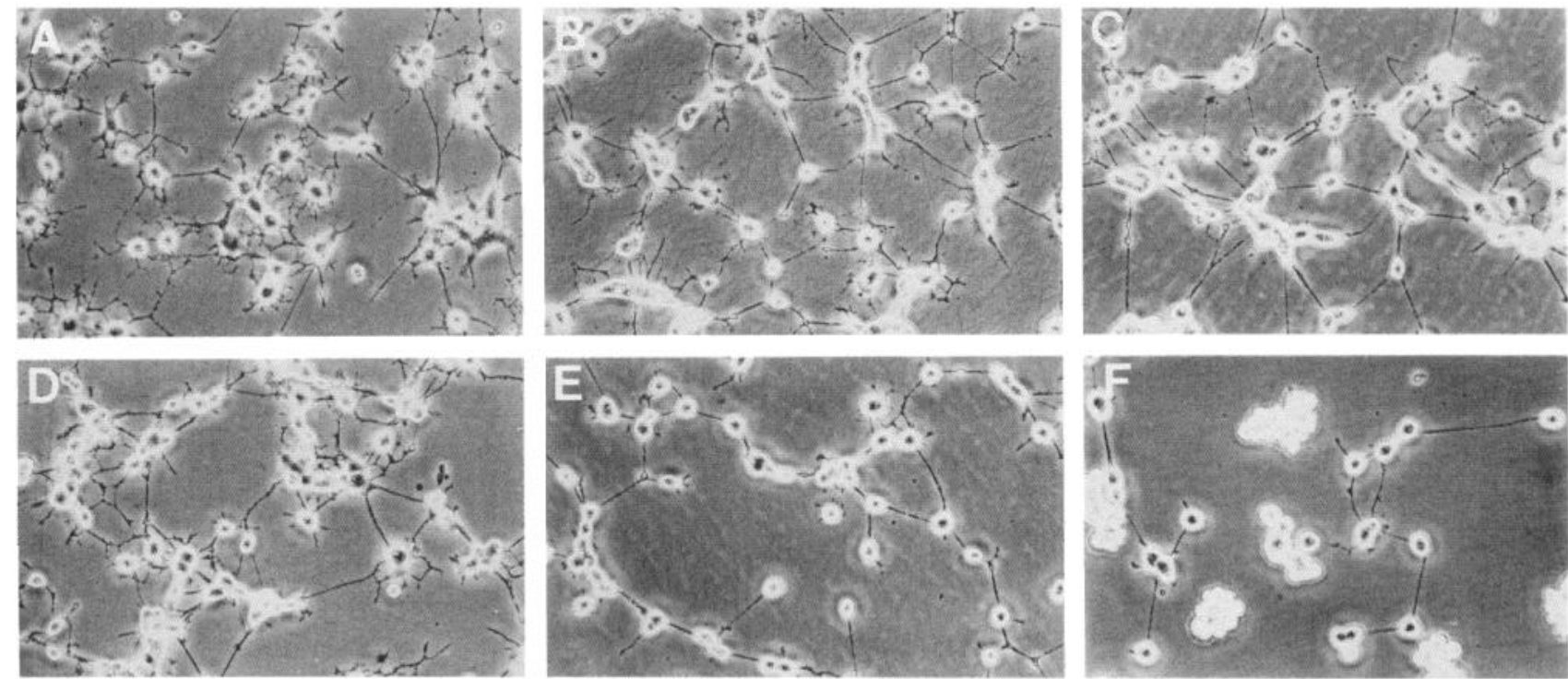

Figure 1. Promotion of neurite retraction and cell detachment by mAbs $1 \mathrm{~B} 1$ and $3 \mathrm{~A} 3$. Cells in NGF-supplemented defined medium were allowed to extend neurites on dishes coated with laminin. After $24 \mathrm{hr}$, the medium was replaced with fresh medium containing PBS at a concentration equivalent to that introduced with mAb $3 \mathrm{~A} 3$ (control, $A$ ) or various concentrations of either $3 \mathrm{~A} 3 \mathrm{or} 1 \mathrm{~B} 1: 10 \mu \mathrm{g} / \mathrm{ml} 1 \mathrm{~B} 1(B), 100 \mu \mathrm{g} / \mathrm{ml} 1 \mathrm{~B} 1(C)$, $0.01 \mu \mathrm{g} / \mathrm{ml} \mathrm{3A} 3(D), 0.1 \mu \mathrm{g} / \mathrm{ml} 3 \mathrm{~A} 3(E)$, and $1 \mu \mathrm{g} / \mathrm{ml} 3 \mathrm{~A} 3(F)$. Six $\mathrm{hr}$ after the medium change, the cultures were fixed with glutaraldehyde, and representative areas were photographed (phase contrast). In other control cultures the fresh medium was supplemented with a volume of carbonate buffer equivalent to that introduced with 1B1 (not shown); there was no evidence of neurite retraction in either control. At the lowest concentrations of the $2 \mathrm{mAbs}$ shown $(B, D)$, there was significant reduction in the number of neurites extended upon the substratum. At 10-fold higher concentrations $(C, E)$, few neurites remained except for those linking cell bodies and many cells had become rounded. The highest concentration of $3 \mathrm{~A} 3(F)$ produced further neurite retraction and cell rounding, and there was marked detachment of cells from the dish. Still higher concentrations of $3 \mathrm{~A} 3$ (not shown) resulted in virtually complete detachment. Essentially identical results were seen with collagen-coated substrata (not shown) $\times 200$.

The other $\mathrm{mAb}, 1 \mathrm{~B} 1$, in addition to inhibiting initial attachment to laminin and collagen, also significantly inhibited attachment to polylysine and WGA (Fig. 5). Thus, when tested at the relatively high concentration of $30 \mu \mathrm{g} / \mathrm{ml}, \mathrm{mAb} 1 \mathrm{~B} 1$ inhibited attachment to collagen by $72 \%$ and laminin by $46 \%$, while inhibiting attachment to polylysine and WGA by 35 and
$68 \%$, respectively. Unlike $3 \mathrm{~A} 3$, therefore, $1 \mathrm{~B} 1$ inhibits both active and passive mechanisms of cell-substratum adhesion.

\section{Identification of $3 A 3$ and $1 B 1$ antigens in PC12 cells}

In immunoprecipitation experiments with detergent extracts of metabolically labeled cells, $3 \mathrm{~A} 3$ specifically precipitated 2 pro-
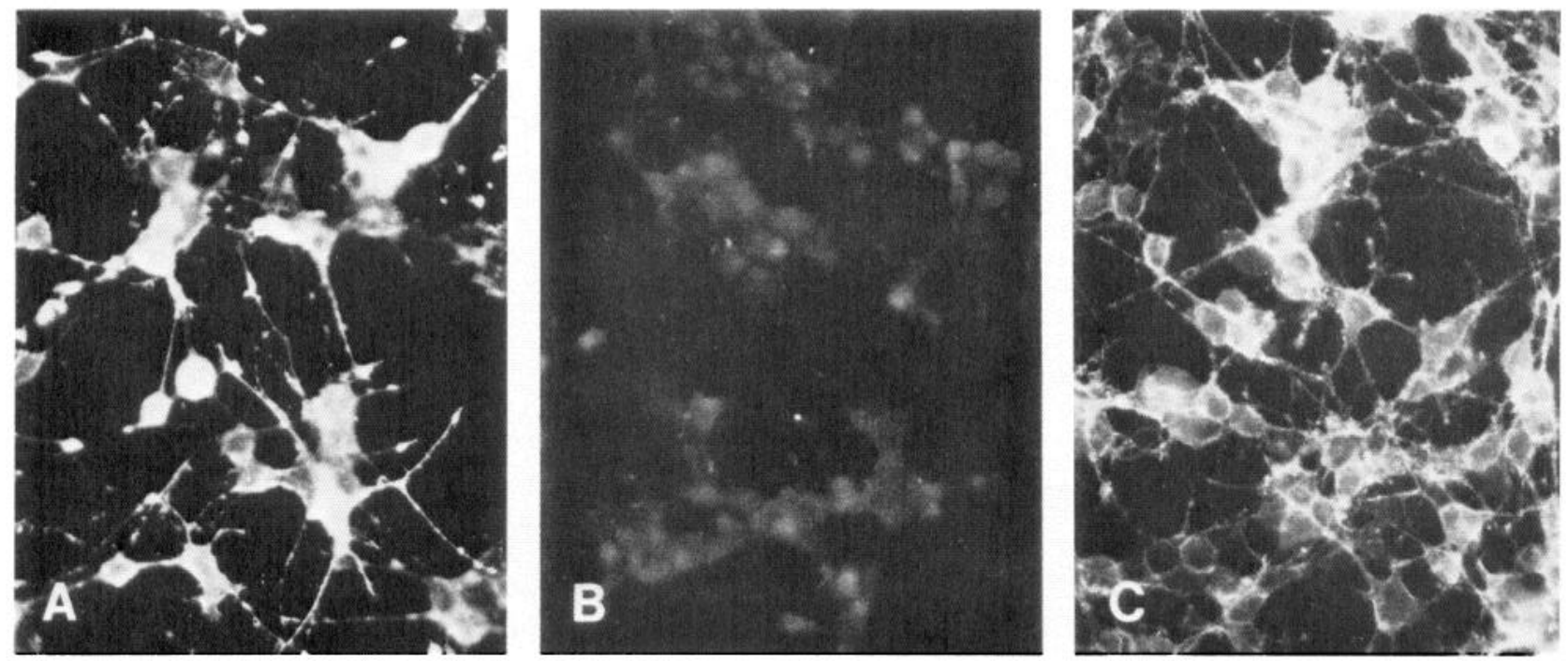

Figure 2. Immunofluorescent detection of $\mathrm{mAb}$ binding to formaldehyde-fixed PC12 cells. Cells were reacted with $10 \mu \mathrm{g} / \mathrm{ml}$ solutions of $1 \mathrm{~B} 1(A)$ or $3 \mathrm{~A} 3(C)$ and then with rhodamine-coupled second antibody. $B, A$ negative control in which the first incubation was with a mAb known not to bind to rat cells (mAb against chick fibronectin, a gift from Dr. M. Chiquet). Both $1 \mathrm{~B} 1$ and $3 \mathrm{~A} 3$ are seen to react positively over the entire cell surface (neurites as well as somata). Labeling with $1 \mathrm{~B} 1$ was always brighter than that with $3 \mathrm{~A} 3$; this difference in intensity was particularly evident when cells were reacted with lower concentrations of $\mathrm{mAb}(0.3-3 \mu \mathrm{g} / \mathrm{ml}$; data not shown $) \times 250$. 

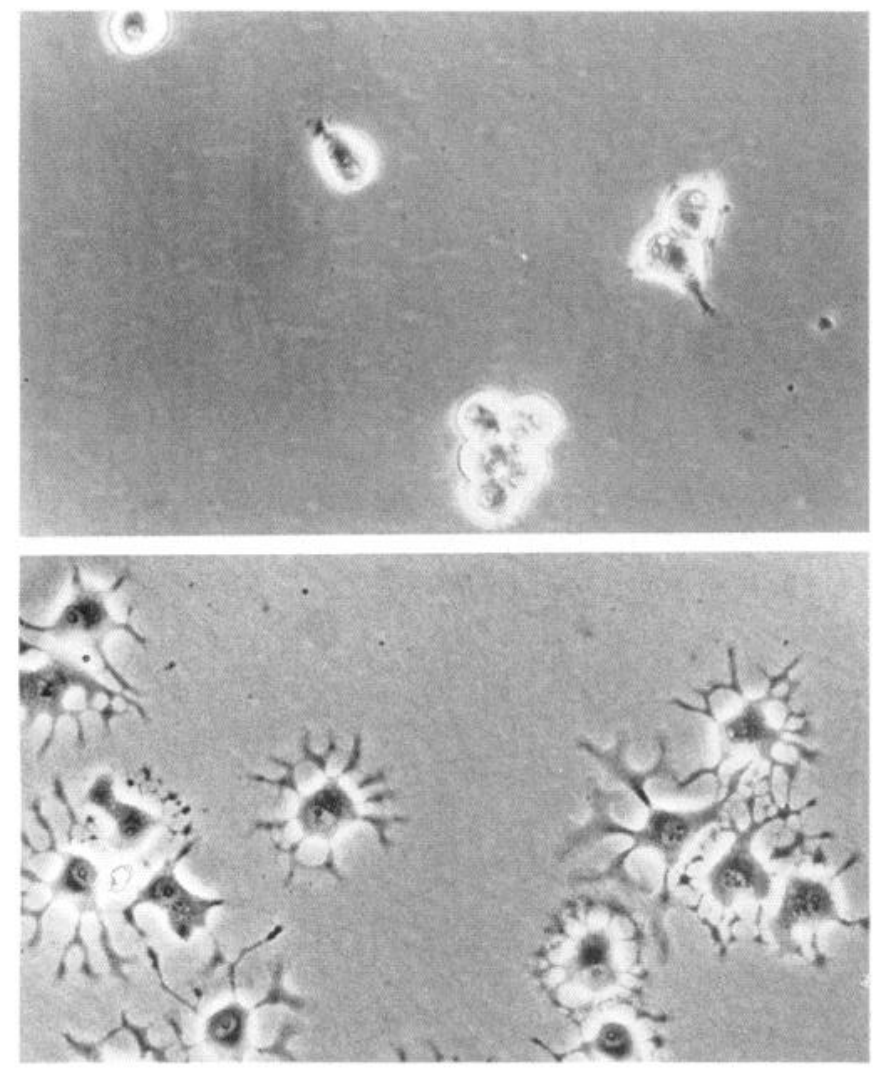

Figure 3. Outgrowth of processes on substrata coated with $3 \mathrm{~A} 3 \mathrm{PC1} 2$ cells primed for $5 \mathrm{~d}$ with NGF were cultured for $22 \mathrm{hr}$ in medium containing NGF ( $300 \mathrm{ng} / \mathrm{ml})$ on uncoated (top) petri plastic dishes or dishes coated (bottom) with $3 \mathrm{~A} 3(10 \mu \mathrm{g} / \mathrm{ml})$. Note that cells attach and extend processes on $3 \mathrm{~A} 3$ but not on uncoated substrata. These processes continue to lengthen for $5 \mathrm{~d}$ or more (longest time tested).

tein bands synthesized by PC12 cells (Fig. 6). In the autoradiographs from the several such experiments undertaken, the higher$M_{r}$ band was always more prominent. The lower band appeared more diffuse and its relative intensity varied. Figure 6 shows an experiment in which the lower band was relatively faint. The same 2 bands were precipitated in the presence of either $1 \mathrm{~mm}$ $\mathrm{MgCl}_{2}$ or $1 \mathrm{~mm}$ EDTA (not shown), indicating that exogenous $\mathrm{Mg}^{2+}$ is not needed to stabilize the epitope(s) recognized by $3 \mathrm{~A} 3$.

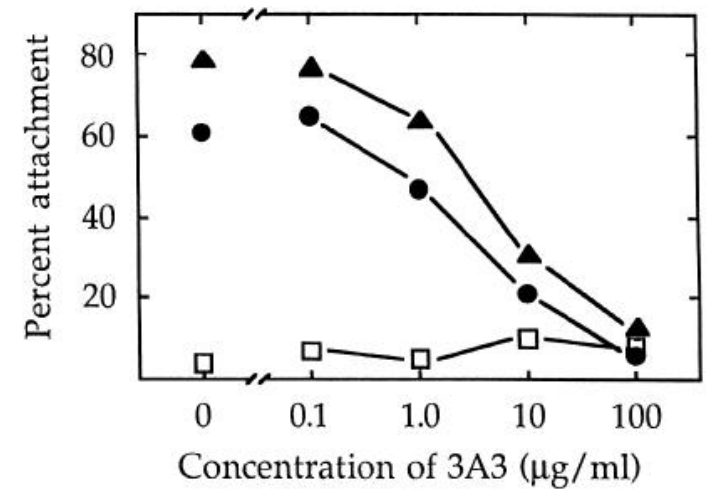

Figure 4. Inhibition of initial attachment as a function of the concentration of mAb $3 A 3$. Petri plates coated with collagen $(\boldsymbol{\Delta})$ or laminin (•) were tested along with uncoated plates $(\square)$ that served as controls. Attachment was measured at $60 \mathrm{~min}$ in the standard assay. Half-maximal inhibition of attachment to substrata coated with either collagen or laminin was observed at a $3 \mathrm{~A} 3$ concentration of about $5 \mu \mathrm{g} / \mathrm{ml}$.

When $3 \mathrm{~A} 3$ beads were used to precipitate proteins from unlabeled cell extracts, the eluates contained 2 protein bands of approximately equal intensity after silver staining (Fig. 7). The apparent $M_{r}$ of both bands was greater after reduction than before (Fig. 7), as is often observed in SDS-PAGE with proteins that have folded conformations stabilized by intrachain disulfide bridges. From the mobilities of the bands relative to markers of known $M_{r}$, we estimate that the larger band has an apparent size of $170 \mathrm{kDa}$ before reduction and $185 \mathrm{kDa}$ after reduction, whereas the smaller band increases from about $110 \mathrm{kDa}$ to about $125 \mathrm{kDa}$ upon reduction. Based on these and other data, we think the proteins specifically precipitated by $3 \mathrm{~A} 3$ are the subunits of a heterodimeric laminin/collagen receptor (see Discussion).

In immunoprecipitation experiments with detergent extracts of labeled cells, 1B1 precipitated many protein bands that differ greatly in $M_{r}$ (not shown). 1B1 also reacted with many $\mathrm{PC} 12$ proteins in immunoblots (see below, Fig. 8).

\section{Monoclonal antibody $1 B 1$ reacts with both subunits of the laminin/collagen receptor}

Detergent-extracted $\mathrm{PC} 12$ proteins (Fig. $8 A$ ) or proteins eluted from $3 A 3$ beads (Fig. $8 B$ ) were separated by SDS-PAGE in the absence of mercaptoethanol, transferred to PVDF membrane,

Table 1. Monoclonal antibodies promote neurite retraction

\begin{tabular}{|c|c|c|c|c|c|}
\hline \multirow[b]{2}{*}{ Supplement } & \multirow{2}{*}{$\begin{array}{l}\text { Cells } \\
\text { remaining } \\
(\%)\end{array}$} & \multirow{2}{*}{$\begin{array}{l}\text { Neurite- } \\
\text { bearing cells } \\
\text { as percent of } \\
\text { cells remaining }\end{array}$} & \multicolumn{3}{|c|}{ Per standard area $\left(1.5 \mathrm{~mm}^{2}\right)$} \\
\hline & & & $\begin{array}{l}\text { Total neurite } \\
\text { length (mm) }\end{array}$ & $\begin{array}{l}\text { Neurite } \\
\text { tips }\end{array}$ & $\begin{array}{l}\text { Neurite } \\
\text { branch points }\end{array}$ \\
\hline None & 100 & 78 & 2.5 & 177 & 23 \\
\hline $3 \mathrm{~A} 3(10 \mathrm{ng} / \mathrm{ml})$ & 88 & 88 & 2.1 & 162 & 13 \\
\hline $3 \mathrm{~A} 3(100 \mathrm{ng} / \mathrm{ml})$ & 100 & 71 & 1.5 & 125 & 5 \\
\hline $3 \mathrm{~A} 3(1 \mu \mathrm{g} / \mathrm{ml})$ & 86 & 53 & 0.7 & 68 & 4 \\
\hline $1 \mathrm{~B} 1(1 \mu \mathrm{g} / \mathrm{ml})$ & 93 & 73 & 1.9 & 147 & 42 \\
\hline 1B1 $(10 \mu \mathrm{g} / \mathrm{ml})$ & 78 & 27 & 0.4 & 33 & 3 \\
\hline
\end{tabular}

Primed cells $\left(10^{5} /\right.$ dish) were plated in NGF-supplemented defined medium on laminin-coated dishes and allowed to extend neurites for $4 \mathrm{hr}$, at which time the medium was replaced with fresh medium containing buffer used to dissolve the $\mathrm{mAb}$ (no supplement) or with fresh medium containing $\mathrm{mAb}$ at the concentration indicated. After an additional 3 $\mathrm{hr}$, plates were fixed with glutaraldehyde. Data presented are averages of duplicate fixed cultures; 40 randomly chosen fields (totaling $1.5 \mathrm{~mm}^{2}$ ) were scored for each dish. 


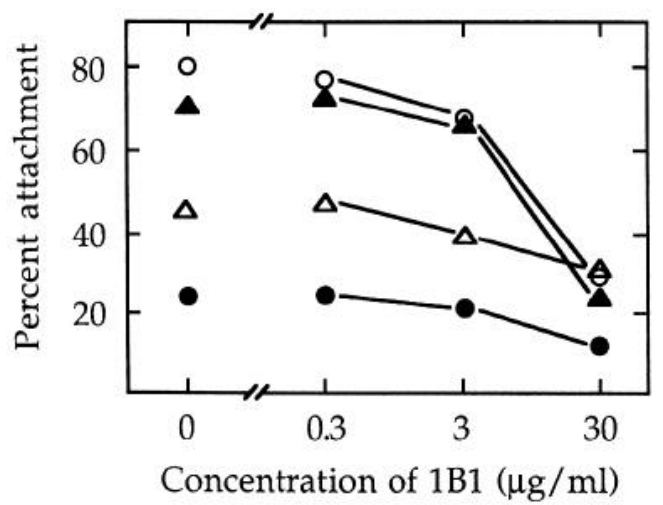

Figure 5. Inhibition of initial attachment as a function of the concentration of $\mathrm{mAb} 1 \mathrm{~B} 1$. Attachment was measured at $120 \mathrm{~min}$ in the scaleddown microwell assay in order to conserve antibody. Petri dishes were coated with collagen $(\boldsymbol{\Delta})$, laminin $(\bullet)$, wheat germ agglutinin $(O)$, or polylysine $(\triangle)$. Unlike $3 \mathrm{~A} 3,1 \mathrm{~B} 1$ inhibits both active and passive attachment (see text). For reasons not understood, maximal attachment to laminin was lower in the scaled-down assay than in the standard assay (see Fig. 3).

and reacted with $3 \mathrm{~A} 3$ or $1 \mathrm{~B} 1$. None of the proteins in the detergent extract of $\mathrm{PC} 12$ cells reacted with $3 \mathrm{~A} 3$ (Fig. $8 \mathrm{~A}$, lane 3 ). Moreover, neither of the bands specifically precipitated by $3 \mathrm{~A} 3$ reacted with $3 \mathrm{~A} 3$ after denaturation and transfer to the PVDF membrane (Fig. $8 B$, lane 3). Attempts to detect the antigen recognized by $3 \mathrm{~A} 3$ in immunoblots of proteins transferred to nitrocellulose were also unsuccessful (not shown).

The other $\mathrm{mAb}, 1 \mathrm{~B} 1$, reacted with many proteins in the $\mathrm{PC} 12$ extract (Fig. 8A, lane 2). The smeared distribution of bound $\mathrm{mAb}$, and the fact that this $\mathrm{mAb}$ reacted with proteins over a wide range of apparent $M_{r}$ suggest that 1B1 may react with a carbohydrate epitope present on many PC12 proteins (see Discussion). Among the many proteins that react with $1 \mathrm{~B} 1$ are both subunits of the putative receptor recognized by $3 \mathrm{~A} 3$ (Fig. $8 B$, lane 2). It is thus possible that the effects of $1 \mathrm{~B} 1$ in inhibiting active attachment and promoting neurite retraction are attributable to binding of this $\mathrm{mAb}$ to the laminin/collagen receptor recognized by $3 \mathrm{~A} 3$ (see Discussion).

\section{Discussion}

The data presented in this paper provide strong evidence, in addition to that adduced earlier (Turner et al., 1987), for the existence of a matrix receptor that mediates neurite outgrowth on both laminin and collagen. Central to this conclusion are the findings that a single $\mathrm{mAb}, 3 \mathrm{~A} 3$, stimulates neurite retraction from substrata coated with either laminin or collagen and that

Table 2. Inhibition of PC12 cell attachment by $3 \mathrm{~A} 3$

\begin{tabular}{lll} 
& \multicolumn{2}{l}{ Percentage of attached cells } \\
\cline { 2 - 3 } Substratum & Control $($ no mAb) & $3 \mathrm{~A} 3(100 \mu \mathrm{g} / \mathrm{ml})$ \\
\hline Collagen & $57.9 \pm 4.5$ & $12.9 \pm 1.5$ \\
Laminin & $51.0 \pm 1.6$ & $10.5 \pm 0.5$ \\
WGA & $75.5 \pm 0.8$ & $73.8 \pm 0.4$ \\
Polylysine & $71.9 \pm 1.4$ & $65.6 \pm 1.6$ \\
Uncoated plastic & $2.1 \pm 0.1$ & $8.8 \pm 0.7$
\end{tabular}

${ }^{a}$ Attachment at $60 \mathrm{~min}$ was measured in the standard attachment assay. Averages of triplicate measurements are shown \pm SEM.

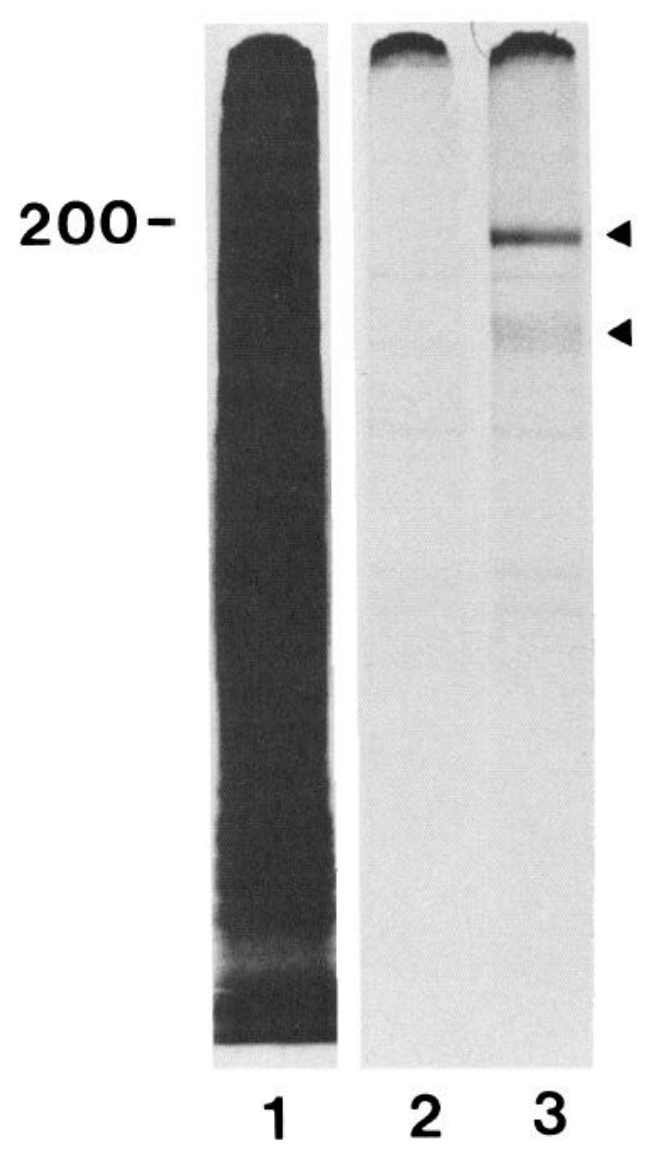

Figure 6. 3A3 specifically precipitates two metabolically labeled proteins from extracts of $\mathrm{PC} 12$ cells. Immunoprecipitation experiment in which samples were not reduced before SDS-PAGE and subsequent autoradiography to reveal labeled proteins. Lane 1, Nonidet-P40 extract of cells incubated for $3 \mathrm{~d}$ with ${ }^{35} \mathrm{~S}$-cysteine and ${ }^{35} \mathrm{~S}$-methionine, not subjected to precipitation $(30 \mu \mathrm{l})$; lane 2 , control without $\mathrm{mAb}$, showing nonspecific precipitation of several labeled proteins; lane 3 , specific precipitation of 2 labeled bands (arrows) by mAb $3 \mathrm{~A} 3(24 \mu \mathrm{g} / \mathrm{ml})$

the same $\mathrm{mAb}$ inhibits active, $\mathrm{Mg}^{2+}$-dependent attachment of cells to laminin or collagen but not passive, divalent cationindependent attachment to polylysine or wheat germ agglutinin. Furthermore, the sizes and electrophoretic behavior of the protein bands precipitated by $3 \mathrm{~A} 3$ suggests that they are subunits of a heterodimer belonging to the integrin family of heterodimeric glycoprotein receptors for matrix molecules.

\section{Relation ship of the PC12 laminin/collagen receptor to other integrins}

Much progress has been made lately in identifying, purifying, and characterizing ECM receptors from a wide variety of cell types. Many ECM receptors belong to a diverse family of heterodimeric molecules designated as "integrins" (reviewed by Hynes, 1987; Ruoslahti and Pierschbacher, 1987). Each integrin consists of several types of $\beta$-subunit (designated $\beta_{1}, \beta_{2}$, etc.) and one of perhaps dozens of different $\alpha$-subunits. Both $\alpha$-and $\beta$-subunits are integral membrane proteins, each consisting of a small cytoplasmic domain, a membrane-spanning segment, and a large extracellular domain. Integrin $\alpha$-subunits are generally larger than $\beta$-subunits (Hynes, 1987). The $\beta$-subunits define integrin subfamilies; members of the $\beta_{2}$ subfamily appear to be found 
mainly on lymphoid and myeloid cells, while integrins of some other subfamilies are widely distributed. Often, a given cell will express multiple integrins; these distinct receptors may belong to different subfamilies (e.g., $\beta_{1}$ and $\beta_{3}$ ). Integrins have different, but sometimes overlapping, specificities in binding ECM components. Thus, some $\beta_{1}$ and $\beta_{3}$ integrins recognize a sequence (Arg-Gly-Asp) present in fibronectin and certain other ECM proteins (Ruoslahti and Pierschbacher, 1987). The specificity of each integrin appears to depend largely on the particular $\alpha$-subunit present.

We have suspected that the antigen recognized by $3 \mathrm{~A} 3$ is an integrin for several reasons: (1) The 2 nonidentical bands precipitated by $3 \mathrm{~A} 3$ are consistent with a heterodimeric structure. Moreover, the apparent sizes of the proteins and their decreased mobility upon reduction are consistent with the sizes and electrophoretic behavior of the larger $\alpha$ - and smaller $\beta$-subunits of known integrins (Hynes, 1987). (2) There are several examples of integrins with affinity for multiple, structurally diverse, ECM molecules (e.g., Haverstick et al., 1985; Akiyama et al., 1986; Pytela et al., 1986). (3) Integrin $\alpha$-chains are known to possess binding sites for divalent cations and some integrins with a specific requirement for $\mathrm{Mg}^{2+}$ are known (Springer et al., 1987).

Polyclonal antisera that react with vertebrate integrins generally react poorly, if at all, with $\alpha$-subunits but react strongly with $\beta$-subunits of the same subfamily, often across species lines (Buck and Horwitz, 1987). Thus, by using antisera known to react with either $\beta_{1}$ - or $\beta_{3}$-subunits, one can assess whether the $3 \mathrm{~A} 3$ antigen belongs to the integrin family. We have taken this approach in recent work completed since the submission of this manuscript (L. Flier and D. Turner, unpublished observations). In these immunoblotting experiments, antisera against the human vitronectin receptor (Telios) and against human platelet glycoprotein IIb/IIIa (a gift from Dr. K. Knudsen) were taken to be specific for $\beta_{3}$-integrins; antisera against the human fibronectin receptor (Telios) and against the $140 \mathrm{kDa}$ subunit of the chicken fibronectin receptor (a gift from Dr. K. Yamada) were diagnostic for $\beta_{1}$-integrins. Our data establish (1) that the antigen recognized by $3 \mathrm{~A} 3$ is an integrin; (2) that the smaller of the 2 bands precipitated by $3 \mathrm{~A} 3$ is the $\beta$-chain of this receptor (and that the larger protein must therefore be the $\alpha$-chain); and (3) that the $\beta$-chain is a member of the $\beta_{1}$ class, placing this laminin/ collagen receptor in the $\beta_{1}$ subfamily of ECM receptors.

Earlier studies by others had shown that antibodies against $\beta_{1}$-integrins interfered with neuronal attachment to, and neurite outgrowth on, substrata coated with collagen or laminin (Bozyczko and Horwitz, 1986; Tomaselli et al., 1986, 1987; Hall et al., 1987). Indeed, Tomaselli et al. (1987) had shown this inhibition for PC12 cells - the same rat neuronal cell line used in our studies - so it was not unexpected that the receptor(s) on PC12 cell surfaces for laminin and collagen would turn out to be $\beta_{1}$-integrin(s). Tomaselli et al. $(1987,1988)$ have used anti$\beta_{1}$ antibodies to precipitate from PC12 cell extracts a mixture of $2 \beta_{1}$-integrins, including one with a large $\alpha$-subunit of approximately the same size $(180 \mathrm{kDa})$ as the one reported in this paper; however, it is not clear from their results whether there are separate receptors for laminin and collagen or whether the mixture includes one dual-function receptor for laminin and collagen and another $\beta_{1}$-receptor of unknown specificity. We think it very likely that the $3 \mathrm{~A} 3$ antigen is identical to one of the $\beta_{1}$-integrins in the mixture obtained by Tomaselli et al. (1988); work is now in progress to test the identity of the receptors from the 2 laboratories. Ignatius and Reichardt (1988)

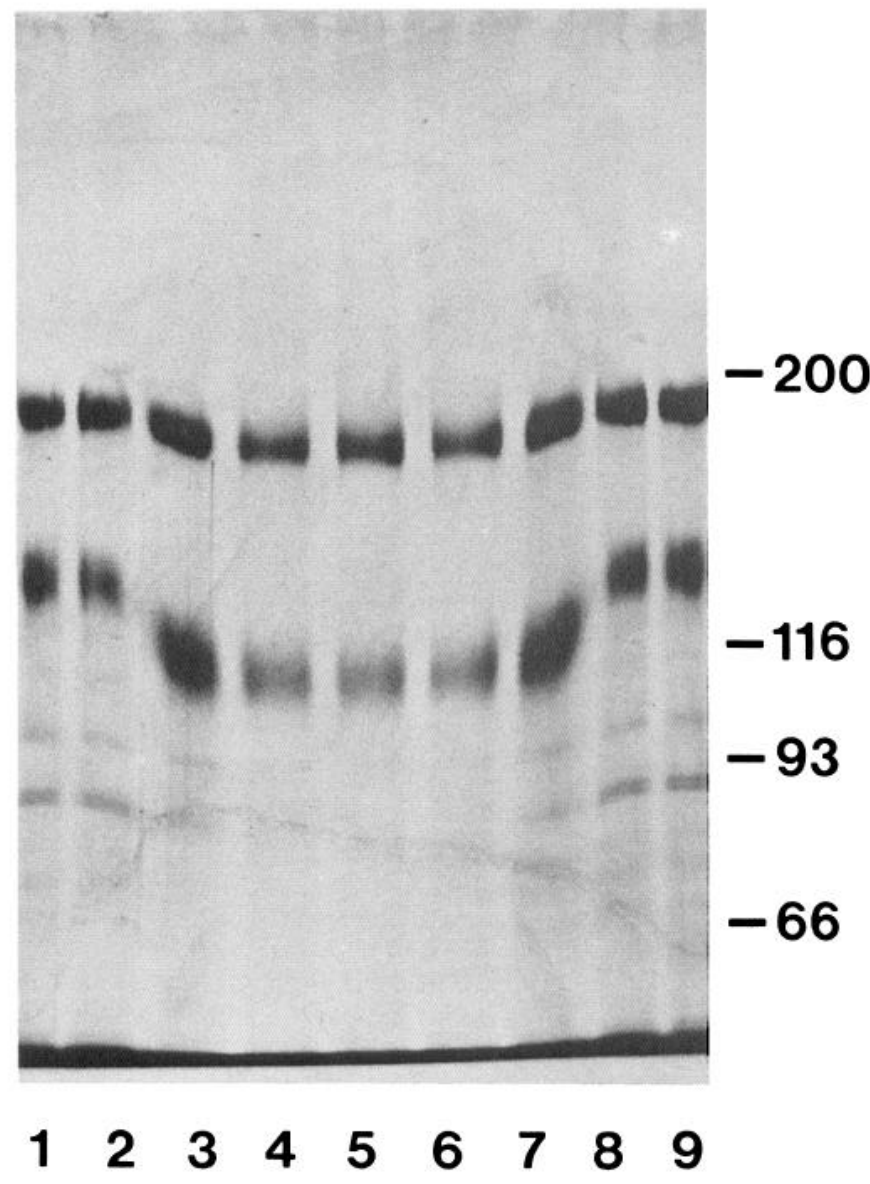

Figure 7. Both protein bands precipitated by $3 \mathrm{~A} 3$ show reduced electrophoretic mobility upon reduction. The procedure suggested by Allore and Barber (1984) was used to demonstrate the shift in apparent $M$ upon reduction. Samples of eluate from $3 \mathrm{~A} 3$ beads were heated with SDS sample buffer either in the presence or absence of mercaptoethanol and electrophoresed according to the following scheme: lanes 1, 2, 8, and 9 , reduced samples; lanes 3-7, nonreduced samples. Proteins separated in a $5 \%$ gel were detected by silver staining. Note that diffusion of mercaptoethanol into adjacent lanes affected the mobilities of the proteins in lanes 3 and 7 .

have purified a single $\beta_{1}$-integrin from extracts of B50 cells, another rat neuronal line. This receptor, which has an $\alpha$-subunit of about $200 \mathrm{kDa}$ and a $\beta$-subunit of about $120 \mathrm{kDa}$, requires $\mathrm{Mg}^{2+}$ or $\mathrm{Mn}^{2+}$ for binding to laminin; binding to collagen was not assessed. This receptor is likely to be very similar to the one on PC12 cells, and perhaps identical. Last, Kleinman et al. (1988) have used laminin-affinity chromatography to enrich for 2 protein bands $(110,180 \mathrm{kDa})$ from detergent extracts of NG108 cells. They show that antibodies against either of these proteins inhibit process formation by NG108 cells on laminin-coated substrata. It is possible, therefore, that these 2 bands identified by Kleinman et al. correspond to the $\beta_{1}$ and $\alpha$-chains coprecipitated by $3 \mathrm{~A} 3$.

Somewhat more difficult to assess is the relationship of the neuronal laminin/collagen receptor to other known $\beta_{1}$-integrins. The size of the $\alpha$-chain is larger than most; also, unlike many $\alpha$-chains, it does not consist of 2 fragments (resulting from proteolytic cleavage) held together by intrachain disulfide(s) (Hynes, 1987). Two of the VLA antigens (VLA-1 and VLA-2) first discovered on human lymphocytes (Hemler et al., 1987) also occur 
A

Figure 8. 1B1 reacts with both subunits of the antigen precipitated by $3 \mathrm{~A} 3$. Blots of Nonidet-P40 extract $(A)$ and of eluate from $3 \mathrm{~A} 3$ beads $(B)$. Strips reacted with india ink confirm transfer of the many proteins in the extract ( $A$, lane $1)$ and of the purified laminin/collagen receptor $(B$, lane $I)$ to the PVDF membrane. Immunoblots are shown according to the following scheme in both $A$ and $B$ : lane 2, $1 \mathrm{~B} 1(5 \mu \mathrm{g} / \mathrm{ml})$; lane 3 , $3 \mathrm{~A} 3(5 \mu \mathrm{g} / \mathrm{ml})$; lane 4 , no primary antibody. Note that $1 \mathrm{~B} 1$ reacts with both protein bands eluted from $3 \mathrm{~A} 3$ beads (B, lane 2).

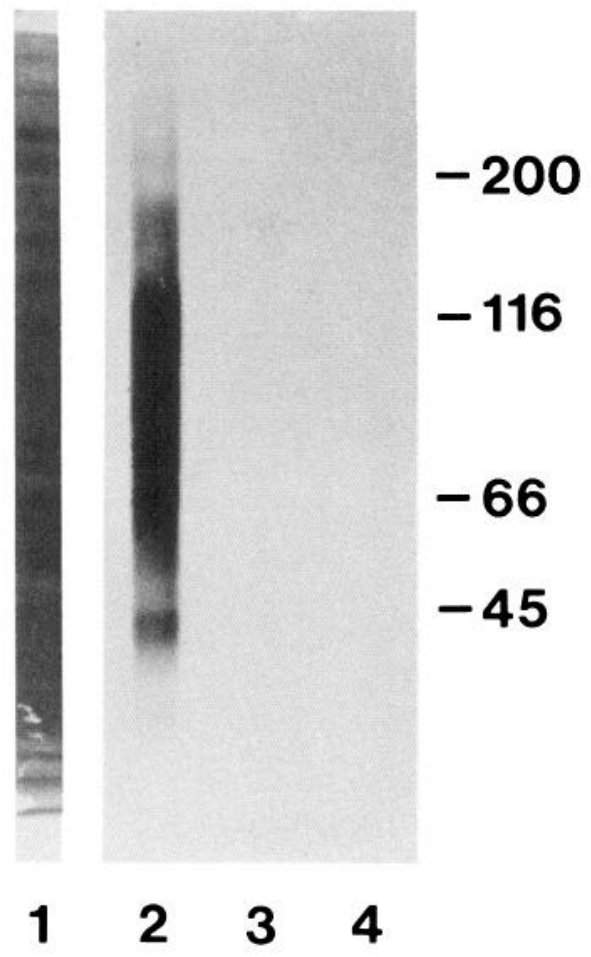

B

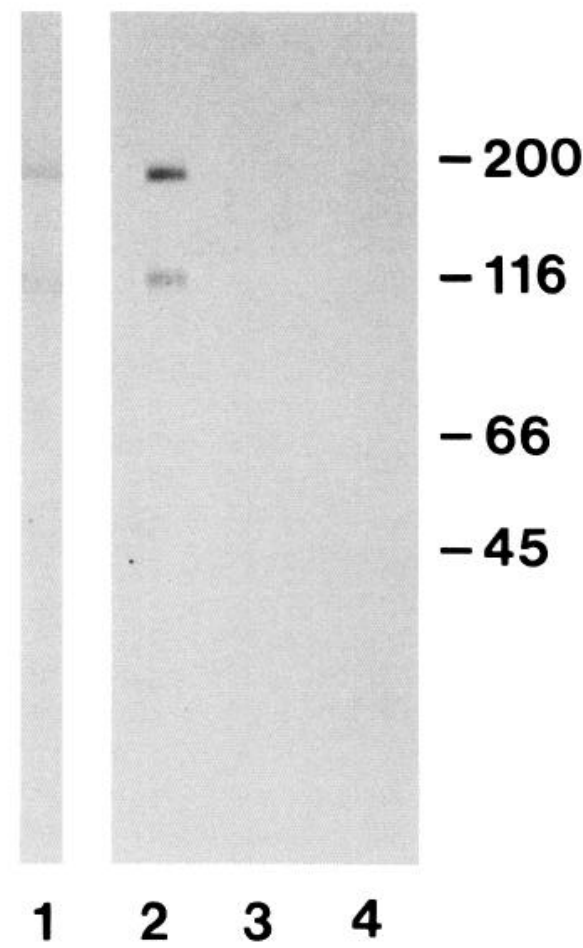

on a human neuronal cell line (Pischel et al., 1986). Of these $\beta_{1}$-integrins, VLA- 1 has an $\alpha$-chain of $180-200 \mathrm{kDa}$ and may therefore be the human counterpart of the antigen recognized by $3 \mathrm{~A} 3$. On the other hand, VLA-2 $(\alpha$-chain $=160 \mathrm{kDa})$ is thought to bind to collagen in a $\mathrm{Mg}^{2+}$-dependent manner (Santoro, 1986; Wayner and Carter, 1987) and so, despite the smaller $\alpha$-chain, may be the integrin on human neurons that most resembles the $3 \mathrm{~A} 3$ antigen in function.

\section{Specificity of the monoclonal antibodies}

There are 2 reasons for thinking that $3 \mathrm{~A} 3$ probably reacts with an epitope on the larger of the 2 bands (presumed $\alpha$-subunit). (1) In early immunoprecipitation experiments with extracts of metabolically labeled PC12 cells, the $\alpha$-subunit band was often much more intensely labeled than the $\beta$-subunit band (see, e.g., Fig. 5). It seems possible that the lower- $M_{r} \beta$-subunit was differentially lost during washing of immunoprecipitates. A differential loss of this sort might happen under certain circumstances if $\alpha$-, but not $\beta$-, subunits were directly bound by antibody, e.g., if antibody binding were to destabilize the heterodimeric complex or if subunit-subunit interactions were weakened under the experimental conditions used. (2) An antibody that reacted with $\beta_{1}$-subunits might be expected to precipitate 2 $\beta_{1}$-integrins from PC12 cells (Tomaselli et al., 1987). Further studies are needed, however, to confirm that the epitope recognized by $3 \mathrm{~A} 3$ is on the $\alpha$-subunit.

The failure of $3 \mathrm{~A} 3$ to react with the receptor following denaturation and blotting suggests that this $\mathrm{mAb}$ reacts with a conformation-dependent peptide determinant. The ability of $1 \mathrm{~B} 1$ to bind to many different PC12 cell proteins, including both subunits of the laminin/collagen receptor, suggests that this $\mathrm{mAb}$ reacts with a carbohydrate moiety present on many PC12 glycoproteins. Further work is needed to test these propositions.

The apparent failure of even high concentrations of $3 \mathrm{~A} 3$ to interfere with cell-to-cell adhesion is consistent with earlier evidence that distinct molecular mechanisms underlie neuron-ECM and neuron-neuron adhesion (reviewed by Jessell, 1988). Neuron-neuron adhesion is likely to involve either N-CAM or $\mathrm{N}$-cadherin and thus should not be inhibited by $3 \mathrm{~A} 3$. An alternative explanation would be that intact, bivalent, $3 \mathrm{~A} 3$ antibodies crosslink cells. Experiments with univalent (e.g., Fab') fragments of $3 \mathrm{~A} 3$ are needed to rule out this possibility.

The functional specificity of $3 \mathrm{~A} 3$ in interfering with active but not passive adhesion will, we believe, be of great value in attempts to probe the adhesive behavior of neuronal growth cones. We had noted earlier (Turner et al., 1987) that Type IV collagen, one of the ECM molecules encountered by neuronal processes in vivo, promotes $\mathrm{PC} 12$ cell adhesion via both passive and active mechanisms. By using $3 \mathrm{~A} 3$ to inhibit selectively 1 of the 2 adhesion mechanisms, we should be able to gain greater insights into the role of active, receptor-mediated, cell-matrix adhesion during neurite outgrowth. The other $\mathrm{mAb}, 1 \mathrm{~B} 1$, binds to the same receptor recognized by $3 \mathrm{~A} 3$; this binding presumably accounts for its ability to interfere with active attachment. Further studies with the mAbs will be needed, however, to establish for each $\mathrm{mAb}$ whether it inhibits ligand binding, receptor clustering, or some other process.

\section{Specificity of the receptor}

The data in this paper, when taken together with data from our earlier paper (Turner et al., 1987), provide strong evidence for a receptor that is capable of binding to both laminin and collagen 
and requires $\mathrm{Mg}^{2+}$. To the best of our knowledge, it is the first description of a matrix receptor with this divalent cation and ligand specificity. As noted above, VLA-2 is thought to bind collagen in a $\mathrm{Mg}^{2+}$-dependent manner and may be identical to the $\mathrm{Mg}^{2+}$-dependent collagen receptor on platelets (Santoro, 1986), but its affinity for laminin is not known. The chicken integrin complex contains a laminin receptor (Horwitz et al., 1985), and there is evidence for a collagen-binding integrin (Buck et al., 1986), but to our knowledge there has been no report of a dual laminin/collagen receptor of the integrin type.

While our evidence clearly supports the existence of a receptor able to bind either laminin or collagen, further experiments will be needed to show that the isolated receptor actually binds to collagen and laminin in a $\mathrm{Mg}^{2+}$-dependent manner (see Ignatius and Reichardt, 1988). Moreover, our work leaves open whether the same receptor can bind to other matrix molecules as well. We showed earlier (Turner et al., 1987) that PC12 cell attachment to native collagen Type II is $\mathrm{Mg}^{2+}$ dependent and that attachment to collagen Type IV is partially $\mathrm{Mg}^{2+}$ dependent, so we would expect the receptor to bind to these collagens in addition to the interstitial collagen used in the work reported in this paper. Whether the isolated receptor has affinity for these and other collagen types remains to be determined. PC12 cells do not attach well to fibronectin, so it is unlikely that the laminin/collagen receptor has affinity for fibronectin. Yet, in view of the ever-increasing number of known ECM proteins (potential ligands), it will be important to undertake studies designed to further define the specificity of the receptor for macromolecular ligands.

In this connection, it will be of interest to elucidate the structure of that part (or parts) of laminin and collagen that is (are) bound by the receptor. Akeson and Warren (1986) and Tomaselli et al. (1987) showed that attachment of, and neurite extension by, PC12 cells on laminin is not inhibited by a synthetic peptide containing the Arg-Gly-Asp sequence. It is therefore unlikely that the receptor we have identified belongs to the group of integrins that recognize the Arg-Gly-Asp sequence. Studies with fragments of laminin produced by limited proteolysis have revealed distinct cell-binding regions (Edgar et al., 1984; Engvall et al., 1986; Aumailley et al., 1987). One, near where the short arms meet, is retained on fragment 1 and mediates the attachment of a variety of cell types including neurons (Edgar et al., 1984). This region also contains the sequence TyrIle-Gly-Ser-Arg, which is recognized by a high-affinity $68 \mathrm{kDa}$ laminin binding protein (Graf et al., 1987). Antibodies against this laminin binding protein do not interfere with process outgrowth by NG108 cells (Kleinman et al., 1988). Moreover, culture substrata coated with peptides containing the Tyr-Ile-GlySer-Arg sequence do not promote neurite outgrowth (Graf et al., 1987). These findings may indicate that laminin fragment 1 contains 2 or more distinct sites of interaction with cell surfaces. Another cell-binding region, located near the end of the long arm and retained on fragment 8 , was originally detected by virtue of its ability to promote neurite outgrowth (Edgar et al., 1984); it also mediates attachment to certain non-neuronal cells (Aumailley et al., 1987). The structural features within fragment 8 that are necessary for cell attachment and neurite outgrowth have not bcen defincd, nor has a receptor specific for this region been described. Whatever the region of laminin recognized by the laminin/collagen receptor described here, we can expect it to bind in a $\mathrm{Mg}^{2+}$-dependent manner and to recognize a structure found in several native collagens in addition to laminin.

\section{References}

Acheson, A., D. Edgar, R. Timpl, and H. Thoenen (1986) Laminin increases both levels and activity of tyrosine hydroxylase in calf adrenal chromaffin cells. J. Cell Biol. 102: 151-159.

Akers, R. M., D. F. Mosher, and J. E. Lilien (1981) Promotion of retinal neurite outgrowth by substrate-bound fibronectin. Dev. Biol. 96: 179-188.

Akeson, R., and S. L. Warren (1986) PC12 adhesion and neurite formation on selected substrates are inhibited by some glycosaminoglycans and a fibronectin-derived tetrapeptide. Exp. Cell Res. 162: $347-362$.

Akiyama, S. K., S. S. Yamada, and K. M. Yamada (1986) Characterization of a $140 \mathrm{kD}$ avian cell surface antigen as a fibronectinbinding molecule. J. Cell Biol. 102: 442-448.

Allore, R. J., and B. H. Barber (1984) A recommendation for visualizing disulfide bonding by one-dimensional sodium dodecyl sulfatepolyacrylamide gel electrophoresis. Anal. Bioch. 137: 523-527.

Aumailley, M., V. Nurcombe, D. Edgar, M. Paulsson, and R. Timpl (1987) The cellular interactions of laminin fragments: Cell adhesion correlates with two fragment-specific high affinity binding sites. J. Biol. Chem. 262: 11532-11538.

Bottenstein, J., and G. Sato (1979) Growth of a rat neuroblastoma cell line in serum-free supplemented media. Proc. Natl. Acad. Sci. USA 76: 514-517.

Boucaut, J.-C., T. Darribere, T. J. Poole, H. Aoyama, K. M. Yamada, and J.-P. Thiery (1984) Biologically active synthetic peptides as probes of embryonic development: A competitive peptide inhibitor of fibronectin function inhibits gastrulation in amphibian embryos and neural crest cell migration in avian embryos. J. Cell Biol. 99: 1822-1830.

Bozyczko, D., and A. F. Horwitz (1986) The participation of a putative cell surface receptor for laminin and fibronectin in peripheral neurite extension. J. Neurosci. 6: 1241-1251.

Bronner-Fraser, M. (1986) An antibody to a receptor for fibronectin and laminin perturbs cranial neural crest cell development in vivo. Dev. Biol. 117: 528-536.

Buck, C. A., and A. F. Horwitz (1987) Cell surface receptors for extracellular matrix molecules. Annu. Rev. Cell Biol. 3: 179-205.

Buck, C., J. A. Drebin, C. Glineur, and D. Portetelle (1986) Purification of mouse monoclonal antibodies from ascitic fluid by DEAE Affi-Gel Blue chromatography. Methods Enzymol. 121: 587-597.

Campbell, A. M. (1984) Monoclonal Antibody Technology, Elsevier, New York.

Carbonetto, S. T., M. M. Gruver, and D. C. Turner (1982) Nerve fiber growth on defined hydrogel substrates. Science 216: 897-899.

Carbonetto, S., M. M. Gruver, and D. C. Turner (1983) Nerve fiber growth in culture on fibronectin, collagen and glycosaminoglycan substrates. J. Neurosci. 3: 2324-2335.

Edgar, D., R. Timpl, and H. Thoenen (1984) The heparin-binding domain of laminin is responsible for its effects on neurite outgrowth and neuronal survival. EMBO J. 3: 1463-1468.

Engvall, E., G. E. Davis, K. Dickerson, E. Ruoslahti, S. Varon, and M. Manthorpe (1986) Mapping of domains in human laminin using monoclonal antibodies: Localization of the neurite-promoting site. J. Cell Biol. 103: 2457-2465.

Graf, J., Y. Iwamoto, M. Sasaki, G. R. Martin, H. K. Kleinman, F. A. Robey, and Y. Yamada (1987) Identification of an amino acid sequence in laminin mediating cell attachment, chemotaxis, and receptor binding. Cell 48: 989-996.

Greene, L. A. (1978) Nerve growth factor prevents the death and stimulates neuronal differentiation of clonal $\mathrm{PCl} 2$ pheochromocytoma cells in serum-free medium. J. Cell Biol. 78: 747-755.

Greene, L. A., and A. S. Tischler (1976) Establishment of a noradrenergic clonal line of rat adrenal pheochromocytoma cells which respond to nerve growth factor. Proc. Natl. Acad. Sci. USA 73: 24242428.

Greene, L. A., and A. S. Tischler (1982) PC12 pheochromocytoma cultures in neurobiological research. Adv. Cell Neurobiol. 3: 373414. 
Grinnell, F. (1978) Cellular adhesiveness and extracellular substrata. Int. Rev. Cytol. 53: 65-144.

Guroff, G. (1985) PC12 cells as a model of neuronal differentiation. In Cell Culture in the Neurosciences, J. E. Bottenstein and G. Sato, eds., pp. 245-271, Plenum, New York.

Hall, D. E., K. M. Neugebauer, and L. F. Reichardt (1987) Embryonic neural retina cell response to extracellular matrix proteins: Developmental changes and effects of the cell substratum attachment antibody (CSAT). J. Cell Biol. 104: 623-634.

Hammarback, J. A., S. L. Palm, L. T. Furcht, and P. C. Letourneau (1985) Guidance of neurite outgrowth by pathways of substratumadsorbed laminin. J. Neurosci. Res. 13: 213-220.

Haverstick, D. M., J. F. Cowan, K. M. Yamada, and S. A. Santoro (1985) Inhibition of platelet adhesion to fibronectin, fibrinogen, and von Willebrand factor substrates by a synthetic tetrapeptide derived from the cell-binding domain of fibronectin. Blood 66: 946-952.

Heidemann, S. R., H. C. Joshi, A. Schechter, J. R. Fletcher, and M. Bothwell (1985) Synergistic effects of cyclic AMP and nerve growth factor on neurite outgrowth and microtubule stability of PC12 cells. J. Cell Biol. 100: 916-927.

Hemler, M. E., C. Huang, and L. Schwarz (1987) The VLA protein family. J. Biol. Chem. 262: 3300-3309.

Horwitz, A., K. Duggan, R. Greggs, C. Decker, and C. Buck (1985) The cell-substrate attachment (CSAT) antigen has properties of a receptor for laminin and fibronectin. J. Cell Biol. I0I: 2134-2144.

Hynes, R. O. (1987) Integrins: A family of cell surface receptors. Cell 48: 549-554.

Ignatius, M. J., and L. F. Reichardt (1988) Identification of a neuronal laminin receptor: An $\mathrm{M}_{\mathrm{r}} 200 \mathrm{~K} / 120 \mathrm{~K}$ integrin heterodimer that binds laminin in a divalent cation-dependent manner. Neuron 1:713-725.

Jessell, T. M. (1988) Adhesion molecules and the hierarchy of neural development. Neuron 1: 3-13.

Kleinman, H. K., R. C. Ogle, F. B. Cannon, C. D. Little, T. M. Sweeney, and L. Luckenbill-Edds (1988) Laminin receptors for neurite formation. Proc. Natl. Acad. Sci. USA 85: 1282-1286.

Laemmli, U. (1970) Cleavage of structural protein during the assembly of the head of bacteriophage T4. Nature 227: 680-685.

Lander, A. D., D. Fujii, and L. F. Reichardt (1985) Laminin is associated with the "neurite outgrowth-promoting factors" found in conditioned media. Proc. Natl. Acad. Sci. USA 82: 2183-2187.

Manthorpe, M., E. Engvall, E. Ruoslahti, F. M. Longo, G. E. Davis, and S. Varon (1983) Laminin promotes neuritic regeneration from cultured peripheral and central neurons. J. Cell Biol. 97: 1882-1890.

Merrie, C. R., D. Goldman, S. A. Sedman, and M. H. Ebert (1981) Ultrasensitive stain for proteins in polyacrylamide gels shows regional variations in cerebrospinal fluid proteins. Science 211: 1437-1438.

Miller, J. L., J. M. Kupinski, and K. O. Hustad (1986) Characterization of a platelet membrane protein of low molecular weight associated with platelet activation following binding by monoclonal antibody AG-1. Blood 68: 743-751.

Nitkin, R. M., B. G. Wallace, M. E. Spira, E. W. Godfrey, and U. J. McMahon (1983) Molecular components of the synaptic basal lamina that direct differentiation of regenerating neuromuscular junctions. Cold Spring Harbor Symp. 48: 653-665.

Pischel, K. D., H. G. Bluestein, and V. L. Woods, Jr. (1986) Very late activation antigens (VLA) are human leukocyte-neuronal cross-reactive cell surface antigens. J. Exp. Med. 164: 393-406.

Pytela, R., M. D. Pierschbacher, M. H. Ginsberg, E. F. Plow, and E. Ruoslahti (1986) Platelet membrane glycoprotein IIb/IIIa: Member of a family of Arg-Gly-Asp-specific adhesion receptors. Science 231: $1559-1562$.
Reh, T. A., T. Nagy, and H. Gretton (1987) Retinal pigmented epithelial cells induced to transdifferentiate to neurons by laminin. Nature 330: 68-71.

Rogers, S. L., P. C. Letourneau, S. L. Palm, J. McCarthy, and L. T. Furcht (1983) Ncuritc extension by peripheral and central nervous system neurons in response to substratum-bound fibronectin and laminin. Dev. Biol. 98: 212-220.

Ruoslahti, E., and M. D. Pierschbacher (1987) New perspectives in cell adhesion: RGD and integrins. Science 235: 491-497.

Sandrock, A. W., Jr., and W. D. Matthew (1987) An in vitro neurite promoting antigen functions in axonal regeneration in vivo. Science 237: $1605-1608$.

Santoro, S. A. (1986) Identification of a 160,000 dalton platelet membrane protein that mediates the initial divalent cation-dependent adhesion of platelets to collagen. Cell 46: 913-920.

Schubert, D., and C. Whitlock (1977) Alteration of cellular adhesion by nerve growth factor. Proc. Natl. Acad. Sci. USA 74: 4055-4058.

Springer, T. A., M. L. Dustin, T. K. Kishimoto, and S. D. Marlin (1987) The lymphocyte function-associated LFA-1, CD2, and LFA-3 molecules. Annu. Rev. Immunol. 5: 223-252.

Timpl, R., H. Rohde, L. Risteli, U. Ott, P. G. Robey, and G. R. Martin (1982) Laminin. Methods Enzymol. 82: 831-838.

Tomaselli, K. J., L. F. Reichardt, and J. L. Bixby (1986) Distinct molecular interactions mediate neuronal process outgrowth on nonneuronal cell surfaces and extracellular matrices. J. Cell Biol. 103: 2659-2672.

Tomaselli, K. J., C. H. Damsky, and L. F. Reichardt (1987) Interactions of a neuronal cell line (PC12) with laminin, collagen IV, and fibronectin: Identification of integrin-related glycoproteins involved in attachment and process outgrowth. J. Cell Biol. 105: 2347-2358.

Tomaselli, K. J., C. H. Damsky, and L. F. Reichardt (1988) Purification and characterization of mammalian integrins expressed by a rat neuronal cell line (PC12): Evidence that they function as $\alpha / \beta$ heterodimeric receptors for laminin and Type IV collagen. J. Cell Biol. 107: 1241-1252.

Towbin, H., T. Staehelin, and J. Gordon (1979) Electrophoretic transfer of proteins from polyacrylamide gels to nitrocellulose sheets: Procedure and some applications. Proc. Natl. Acad. Sci. USA 76: 43504354.

Turner, D. C. and S. T. Carbonetto (1984) Model systems for studying the functions of extracellular matrix molecules in muscle development. Exp. Biol. Med. 9: 72-79.

Turner, D. C., J. Lawton, P. Dollenmeier, R. Ehrismann, and M. Chiquet (1983) Guidance of myogenic cell migration by oriented deposits of fibronectin. Dev. Biol. 95: 497-504.

Turner, D. C., L. A. Flier, and S. Carbonetto (1987) Magnesiumdependent attachment and neurite outgrowth by PC1 2 cells on collagen and laminin substrata. Dev. Biol. 121: 510-525.

Vlodavsky, I., A. Levi, I. Lax, Z. Fuks, and J. Schlessinger (1982) Induction of cell atlachment and morphological differentiation in a pheochromocytoma cell line and embryonal sensory cells by the extracellular matrix. Dev. Biol. 93: 285-300.

Watt, T. S., and R. M. Watt (1983) Detection of unique antigenic determinants on human plasma low density lipoprotein and on delipidated apolipoprotein B. Proc. Natl. Acad. Sci. USA 80: 124-128.

Wayner, E. A., and W. G. Carter (1987) Identification of multiple cell adhesion receptors for collagen and fibronectin in human fibrosarcoma cells possessing unique $\alpha$ and common $\beta$ subunits. J. Cell Biol. 105: $1873-1884$ 